\title{
Valuing carbon capture in agricultural production: examples from Sweden
}

\author{
K. Linderholm ${ }^{1} \mathbb{D} \cdot$ T. Katterer ${ }^{2} \cdot$ J. E. Mattsson ${ }^{3}$
}

Received: 14 January 2020 / Accepted: 16 June 2020 / Published online: 22 June 2020

(c) The Author(s) $2020 \quad$ OPEN

\begin{abstract}
Agriculture is regarded as a net emitter of greenhouse gases (GHG), but sequesters huge amounts of carbon in soils, bioenergy substrates, and food products. The global accounting system for climate impact based on life cycle assessment (LCA) methodology only takes account of costs (emissions), and not income (carbon and energy binding), leading to the conclusion that agricultural activities should decrease to mitigate climate change. This study considered an alternative accounting system, carbon capture LCA (CC-LCA), that allocates value to carbon sequestration in agricultural products. For two case farms in Sweden (arable, dairy), CC-LCA was applied to (1) calculate the carbon footprint of agricultural production by accounting for net GHG emissions from farm production, rather than gross emissions only, and (2) assess the net impact of mineral nitrogen fertilizer. For the arable farm, CC-LCA revealed net carbon binding of $4 \mathrm{Mg} \mathrm{CO}_{2}$-eq per hectare (net sink), compared with emissions of $1.6 \mathrm{Mg} \mathrm{CO}_{2}$-eq per hectare in LCA. For the dairy farm, both approaches showed emissions of about $10 \mathrm{Mg} \mathrm{CO}_{2}$-eq per dairy cow, mainly due to ruminant digestion. The results also showed that mineral nitrogen fertilizer effectively contributed to carbon sequestration. Compared with an unfertilized wheat crop, a fertilizer dose of $200 \mathrm{~kg} \mathrm{~N} \mathrm{ha}^{-1}$ was estimated to bind about eight-fold more GHG and energy in grain than was released or used during fertilizer production and crop cultivation. Thus, we argue that future strategies aiming for climate-friendly products and practices must acknowledge that agriculture sequesters carbon in products.
\end{abstract}

Keywords Climate change $\cdot$ GHG $\cdot$ LCA $\cdot$ Mineral fertilizer $\cdot$ Carbon capture

\begin{tabular}{|c|c|c|c|}
\hline \multicolumn{2}{|c|}{ Abbreviations } & \multirow{2}{*}{$\begin{array}{l}\text { GWP } \\
\text { ICBM }\end{array}$} & \multirow{2}{*}{$\begin{array}{l}\text { Global warming potential } \\
\text { Introductory carbon balance model }\end{array}$} \\
\hline BAT & Best available technique & & \\
\hline CC-LCA & $\begin{array}{l}\text { Life cycle assessment that takes account of } \\
\text { carbon capture via photosynthesis }\end{array}$ & iLUC & $\begin{array}{l}\text { Indirect land use change, e.g., emissions due } \\
\text { to deforestation for the production of pur- }\end{array}$ \\
\hline $\mathrm{CO}_{2}$-eq & $\begin{array}{l}\text { Carbon dioxide equivalent, a term for describ- } \\
\text { ing different greenhouse gases in a common } \\
\text { unit }\end{array}$ & IPCC & $\begin{array}{l}\text { chased feedstuffs } \\
\text { Intergovernmental Panel on Climate change, } \\
\text { a United Nations body }\end{array}$ \\
\hline DM & Dry matter & ISO & International Organization for \\
\hline ECM & $\begin{array}{l}\text { Energy-corrected milk, adjusted to } 3.14 \mathrm{MJ} / \mathrm{kg} \\
\text { ( } 750 \mathrm{kcal} \text { ) }\end{array}$ & L & $\begin{array}{l}\text { Standardization } \\
\text { Liter }\end{array}$ \\
\hline FAO & $\begin{array}{l}\text { Food and Agriculture Organization of the } \\
\text { United Nations }\end{array}$ & $\begin{array}{l}\text { LCA } \\
\text { LULUCF }\end{array}$ & $\begin{array}{l}\text { Life cycle assessment } \\
\text { Land Use, Land Use Change, and Forestry }\end{array}$ \\
\hline GHG & Greenhouse gases & $\mathrm{Mg}$ & $1,000,000 \mathrm{~g}$ \\
\hline
\end{tabular}

K. Linderholm, kersti.linderholm@silvberg.se | ${ }^{1}$ Silvberg Environmental Technology, Borlange, Sweden. ${ }^{2}$ Department of Ecology, Swedish University of Agricultural Sciences, Uppsala, Sweden. ${ }^{3}$ Department of Biosystems and Technology, Swedish University of Agricultural Sciences, Alnarp, Sweden. 


$\begin{array}{ll}\text { NPK } & \text { Nitrogen, phosphorus, potassium } \\ \text { SEPA } & \text { Swedish Environmental Protection Agency } \\ \text { SOC } & \text { Soil organic carbon } \\ \text { UNFCCC } & \text { United Nations Framework Convention on } \\ & \text { Climate Change }\end{array}$

\section{Introduction}

Climate change is top of the agenda in many countries, and the climate impacts of different sectors are under scrutiny. The Intergovernmental Panel on Climate Change (IPCC) has established a method for calculating emissions of greenhouse gases (GHG) that can be applied at the global level. It is used by the 197 parties to the United Nations Framework Convention on Climate Change (UNFCCC) [1], and thus current reporting covers most emissions sources worldwide. In the IPCC system, each country reports emissions from its domestic production, which reduces the risk of double counting and means that, globally, emissions are accounted for at the site of production. Some carbon pool changes, called Land Use, Land Use Change, and Forestry (LULUCF), which are mainly connected to forestry, are included in the reporting system. However, the IPCC method cannot be used to calculate how climate-friendly nations, regions, or groups of consumers are. Instead, regardless of the end-consumer of a food product, the GHG emissions are placed as a burden on the producing country, which could thus reduce its emissions by reducing its food production.

However, from an environmental perspective, it may be more important for individual countries to change consumption, rather than production. For example, Sweden reported GHG emissions of $52.7 \times 10^{6} \mathrm{Mg}$ carbon dioxide equivalents $\left(\mathrm{CO}_{2}\right.$-eq) in 2017 , based on national production and excluding LULUCF [2]. For a population of around 10 million [3], this represents emissions of about $5.3 \mathrm{Mg}$ $\mathrm{CO}_{2}$-eq per person. However, according to the Swedish Environmental Protection Agency (SEPA), the GHG emissions from consumption in Sweden, regardless of the production site, amount to $10.1 \mathrm{Mg} \mathrm{CO}_{2}$-eq per person and year (2016 values) [4]. Thus, almost half the emissions from consumption in Sweden are generated and accounted for in other countries, unfairly increasing their burden.

The climate impact of food production in agriculture is accounted for in the IPCC system based on the number of animals (mainly ruminants), the amount of manure and fertilizer used, and the acreage of different types of farmland, particularly organic soils. With that accounting system, an easy way to reduce the climate impact of agriculture is simply to reduce the number of animals and/ or the area of fertilized farmland, since other mitigation measures will have less influence on the reported outcome
[2]. This means that achieving significant reductions in the GHG emissions from agriculture according to the IPCC system would lead to decreased domestic production of animal- and plant-based foods, and effectively to the outsourcing of food supply.

However, this accounting approach ignores the fact that agriculture (and forestry) can sequester large amounts of carbon in products through photosynthesis. These products can be used by other sectors as renewable energy substrates, fibers, or food. Food is not considered renewable energy in the IPCC accounting system, although leftovers or certain crops can be used for this purpose through biodigestion or gasification. Thus, while food production is essential for the world's population, in the IPCC accounting system it is only a burden on producing countries. Moreover, in the IPCC system, only a small fraction of the carbon captured in agriculture is accounted for, when changes in management lead to a net increase in soil organic carbon (SOC) [2].

In scientific studies, the climate impact of agricultural production is often measured using a life cycle assessment (LCA) approach, following ISO standards $[5,6]$ and manuals [7]. In LCA, all global warming potential (GWP) from inputs is counted, regardless of whether the inputs are produced inside the country or imported. An LCA approach is employed in the Swedish agricultural extension system to calculate GWP for a certain farm or crop, and the results are generally expressed as emissions of $\mathrm{CO}_{2}$-eq per $\mathrm{kg}$ product [8]. It is possible within LCA to account for carbon sequestration in agricultural products, but this is rarely done. However, if the system boundary is set at the farm gate, the carbon and energy bound in products should be accounted for, whereas emissions of $\mathrm{CO}_{2}$ from consumption of food are caused by the consumer, outside the farm gate. This method of calculation also considers energy or carbon in agricultural products used as a fuel outside the farm. DeCicco [9] suggests carbon accounting where all $\mathrm{CO}_{2}$ emissions from fuel end-use are valued, regardless of the origin of the carbon (forest, agriculture, or fossil). Frankelius [10] reports that agriculture binds huge amounts of $\mathrm{CO}_{2}$ each year in the form of cereals and other crop products, but points out that this photosynthesis effect is not fully considered as a positive.

It is often argued that production of mineral fertilizer is harming the climate, due to its high energy requirement [11]. With a model that only takes account of costs (emissions), and not income (carbon and energy binding), the inevitable conclusion is that all activities in agriculture should decrease. However, this would also mean a decrease in food production. Article 2 of the UNFCCC [12] warns that food production must not be threatened by climate mitigation measures, but in the political debate this is often forgotten and only GWP is discussed. 
Existing labeling or certification systems for agriculture, e.g., organic certification [13], do not consider the efficiency of agriculture, which means that scarcity of good arable land is not considered a limiting resource for future food production. If systems are associated with low efficiency in the production of common agricultural commodities that are traded globally, this will lead to spatial expansion of agriculture and cause indirect land use change (iLUC) and associated GHG emissions [14]. Thus, focusing solely on GHG emissions and ignoring carbon sequestration can result in less climate-friendly decisions.

The aim of this study was to compare conventional LCA with a carbon capture LCA method (CC-LCA) for valuing carbon sequestration in agricultural products used as food and fuel, whereby food production and consumption are separated. The carbon in agricultural products can be used as food, feed, or fuel. In the CC-LCA approach, the GHG emissions from consumption are accounted for at the place and in the sector in which they are consumed, as food or fuel. This allows the carbon footprint of a farm to be calculated in a way that takes into account the net GHG emissions from farm production, and not only the gross emissions. The advantage of this method is that different measures on a farm can be compared, immediately revealing which gives the lowest net emissions in relation to sequestered carbon. The CC-LCA method could thus be used to calculate the net impact on the atmosphere of a particular product, or of all farms within a country, which would allow the real climate impact of agriculture to be assessed and support decisions on more sustainable food production.

To illustrate the impacts and consequences of conventional LCA methodology and the CC-LCA method, we used both approaches to calculate net outputs of GHG and energy for two case farms in Sweden and compared the results obtained. We also used the CC-LCA method to calculate the net impact of mineral nitrogen fertilizer application to a winter wheat crop in Sweden in terms of crop production, GHG emissions, and carbon sequestration.

\section{Methods}

Conventional LCA and carbon capture LCA (CC-LCA) were both used to calculate emissions of GHG from two actual typical farms in Sweden, an arable farm and a dairy farm. In both methods, the GHG emissions from production are charged to the producing farm. However, in CC-LCA, the carbon in products is considered "income" for the producing farm, and if the product is sold as food or fuel, the carbon is charged to the consumer instead of the producer. If the product is sold as animal feed, the carbon is considered an input to animal production, as energy in the feed.

\subsection{Conventional LCA approach}

The conventional LCA calculations for the two farms were performed using a decision support tool called VERA developed by the Swedish Board of Agriculture [15]. It was originally designed to calculate the nutrient balance on farms, but has been extended to include, e.g., GHG emissions in a basic LCA for the farm. It takes a life cycle perspective, which means that the GHG emissions from the production of inputs, such as mineral fertilizer, feed concentrate, and energy, are included to calculate the total GHG emissions from production. The GHG emissions from soil, animals, and manure are also included. The GHG gases assessed are carbon dioxide $\left(\mathrm{CO}_{2}\right)$, methane $\left(\mathrm{CH}_{4}\right)$, and nitrous oxide $\left(\mathrm{N}_{2} \mathrm{O}\right)$. Emissions from fossil sources (e.g., fossil fuels) and from iLUC (e.g., emissions due to deforestation for the production of purchased feedstuffs) are considered. Carbon of biological origin that is likely to be returned quickly to the cycle, such as the carbon bound in feed and food, is not included [16]. The values used for emissions from soil, animals, etc. are in line with those recommended by IPCC.

\subsection{CC-LCA approach}

In our CC-LCA calculations, the system boundary was set around the farm and did not include the consumer. This means that the GHG emissions from inputs, soil, and animal digestion and manure were considered, but also the $\mathrm{CO}_{2}$ bound in cereals produced and in all roughage, milk, and meat sold. Accounting for the carbon content in purchased feed normally gives higher GHG emissions than the conventional LCA approach, which only considers GHG emissions from the production of inputs.

In the CC-LCA calculations, we assumed that $1 \mathrm{~kg}$ carbon in the harvested product captured $3.68 \mathrm{~kg} \mathrm{CO}_{2}$ from the atmosphere, a value based on the molar weight of carbon (12) and oxygen (16). Other assumptions used in the calculations were that plant dry matter contains $45 \%$ carbon [17], milk contains $0.069 \mathrm{Mg}$ carbon per $\mathrm{Mg}$ [18, 19], and living animals contain $18 \%$ carbon $[20,21]$. To avoid double-counting for purchased carbon in feed emitted as methane during digestion or from manure, an adjustment had to be made. The carbon emitted as methane was therefore subtracted from the methane emissions.

The changes in soil organic carbon (SOC) stocks were estimated using the carbon balance model ICBM, which can be applied at different scales from laboratory to field, regional, and national [22-24]. This model is also used in Swedish carbon reporting within the UNFCCC framework $[25,26]$, in LCA applications [27-30], and in farm-scale advisory tools [31, 32]. In the present application, we used the two-pool version of ICBM, with model parameters 
according to Andrén et al. [26]. Carbon inputs through above-ground (straw and stubble) and below-ground (roots, including rhizodeposition) crop residues were calculated from crop yields according to Bolinder et al. [33] for each crop in the rotation on the case farms.

\section{Materials and data}

\subsection{Mineral fertilizer used in the studies}

Both case farms use mineral fertilizer produced by Yara in Norway. We also used Yara fertilizer in calculations of the net impact of mineral nitrogen fertilizer, as it is the most common fertilizer sold in Sweden. The product sold in Sweden is produced with a catalyst technology that reduces the $\mathrm{N}_{2} \mathrm{O}$ emissions from nitric acid plants by $90 \%$ and gives a nitrogen fertilizer with GHG emissions of $3.6 \mathrm{~kg}$ $\mathrm{CO}_{2}$-eq per kg nitrogen, which is well below the European "best available technique" (BAT) level and $50 \%$ below the emissions from the average European plant not operating with BAT. Plants outside Europe generally have even higher carbon footprint than the European average [34].

\subsection{Case farms}

Both case farms are situated in central Sweden and use mineral fertilizer from Yara and renewable electricity (hydropower), which gives low emissions of GHG gases (Table 1).

\subsubsection{Arable farm}

The arable farm has 98 ha of arable land, on which barley, oats, rapeseed, and ley harvested as hay or silage are produced. Annual inputs to the farm are seeds, some plant protection chemicals, and $26 \mathrm{Mg}$ mineral fertilizer as NPK 27-3-3 and $12 \mathrm{Mg}$ as NPK 21-3-10. In crop cultivation, harvest, and some drying of grain, 13,000 L diesel are used. This diesel contains $5 \%$ biodiesel. Electricity is used to dry hay, etc. and $50 \%$ of the grain is dried with left-over biofuels from the farm's own forest. Annual outputs from the farm are $126 \mathrm{Mg}$ oats, $112 \mathrm{Mg}$ malting barley, $20 \mathrm{Mg}$ rapeseed, and $130 \mathrm{Mg}$ dry matter of hay. The nutrient balance shows a deficit of $3 \mathrm{~kg}$ phosphorus and $26 \mathrm{~kg}$ potassium per hectare, which has to be balanced by the soil.

\subsubsection{Dairy farm}

The dairy farm has 71 dairy cows on an annual basis and around 80 heifers and calves, making it slightly smaller than the average dairy farm in Sweden, which has 92 milking cows (2018 values) [35]. Its agricultural land consists
Table 1 Characteristics of the two case farms in Sweden

\begin{tabular}{lll}
\hline & Arable farm & Dairy farm \\
\hline Natural pasture & 0 ha & 15 ha \\
Oats & 28 ha & 0 ha \\
Barley & 28 ha & 25 ha \\
Spring rapeseed & 10 ha & 0 ha \\
Ley & 35 ha & 60 ha \\
Dairy cows & 0 animals & 70 animals \\
Hiefers and calves & 0 animals & 80 animals \\
Main inputs & & \\
Nitrogen fertilizer & $9.5 \mathrm{Mg}$ & $6.7 \mathrm{Mg}$ \\
Phosphorus & $1 \mathrm{Mg}$ & $0 \mathrm{Mg}$ \\
Potassium & $1.8 \mathrm{Mg}$ & $0 \mathrm{Mg}$ \\
Feed concentrates & $0 \mathrm{Mg}$ in DM & $263 \mathrm{Mg}$ in DM \\
Diesel & $13 \mathrm{~m}$ & $11 \mathrm{~m}$ \\
Electricity & $70 \mathrm{MWh}$ & $76 \mathrm{MWh}$ \\
Outputs & & \\
Cereals & $238 \mathrm{Mg}$ & $0 \mathrm{Mg}$ \\
Rape seed & $20 \mathrm{Mg}$ & $0 \mathrm{Mg}$ \\
Hay & $130 \mathrm{Mg}$ in DM & $0 \mathrm{Mg}$ in DM \\
Milk (ECM) & $0 \mathrm{Mg}$ & $772 \mathrm{Mg}$ \\
Animals & $0 \mathrm{Mg}$ & $19.5 \mathrm{Mg}$ \\
\hline
\end{tabular}

of 65 ha ley, 25 ha barley, and 15 ha semi-natural grassland. Some of the cereal and most of the roughage (hay, silage, pasturage, etc.) used as animal feed are grown on the farm, but concentrate for the dairy cows is bought in. Under Swedish law, all cows and heifers must be allowed to graze outdoors in summer and the nutrients in animal manure must be used in an efficient way according to regulations for reducing its environmental impact. The cows on the farm are milked year-round in a voluntary milking system (one milking robot) and produce around $11 \mathrm{Mg}$ energy-corrected milk (ECM) per head and year. The calves are mainly fed on milk from the cows. On an annual basis, the farm sells almost $772 \mathrm{Mg}$ ECM and $19.5 \mathrm{Mg}$ living animals as calves, heifers, or beef animals. In terms of nutrient balance, the farm brings in enough phosphorus and potassium in concentrate for the cows. In total, the farm has a surplus of $10 \mathrm{~kg}$ phosphorus and $27 \mathrm{~kg}$ potassium per hectare. Mineral fertilizer containing only nitrogen and sulfur is bought (20 Mg NS 27-4) and 11,000 L diesel are used annually, of which $5 \%$ is biodiesel.

\subsection{Impact of mineral nitrogen fertilizer}

The Swedish Board of Agriculture evaluates a large number of field experiments every year and reports the economically optimal average fertilizer dose for different crops $[36,37]$. Nitrogen fertilization increases crop production to a certain optimal level (Fig. 1). Exceeding the optimal 


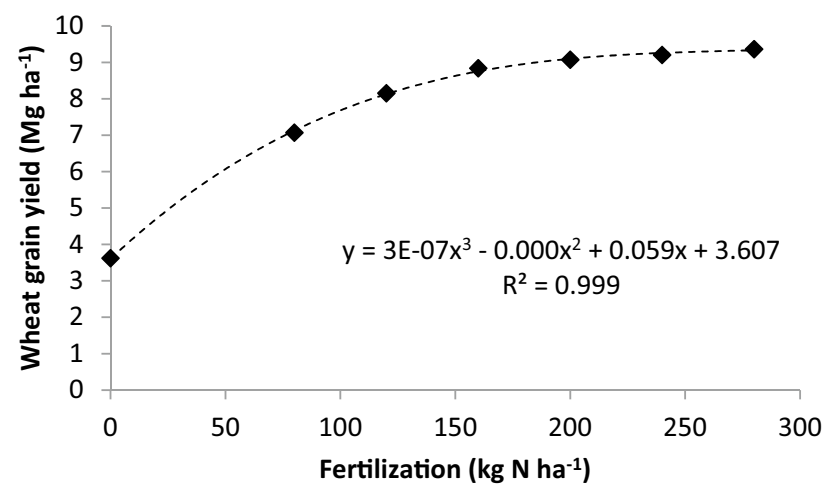

Fig. 1 Yield of winter wheat $\left(\mathrm{Mg} \mathrm{ha}^{-1}\right)$ as a function of nitrogen fertilization rate $\left(\mathrm{kg} \mathrm{ha}^{-1}\right)$. Based on data from 10 years of field trials in southern Sweden. Compiled by Borling and used by the Swedish Board of Agriculture in recommendations to farmers [36]

fertilizer dose decreases nitrogen utilization efficiency and increases the risk of crop lodging and leaching of nitrogen. In the CC-LCA approach in the present study, calculations of net output of energy and GHG emissions when using mineral nitrogen fertilizer were based on 10 years of field experiments with winter wheat in southern Sweden evaluated by the Swedish Board of Agriculture [36]. As input to the calculations, the climate footprint and energy use in producing the mineral fertilizer were considered.

The moisture content in the harvested grain was assumed to be $18 \%$, and it was assumed to be dried to $14 \%$ moisture content. Emissions of $\mathrm{N}_{2} \mathrm{O}$ from the soil after the application of mineral fertilizer and manure were calculated according to UNFCC guidelines:

$\mathrm{N}_{2} \mathrm{O}$ emissions $=\mathrm{NFERT} \times \mathrm{EF} 1 \times 44 / 28$

where NFERT is the amount of mineral nitrogen fertilizer used, EF1 is an emissions factor ( $1 \%$ of NFERT), and $44 / 28$ is a conversion factor from $\mathrm{N}_{2} \mathrm{O}-\mathrm{N}$ to $\mathrm{N}_{2} \mathrm{O}$, where $\mathrm{GWP}_{100}$ for $1 \mathrm{~kg} \mathrm{~N} 2 \mathrm{O}$ is $298 \mathrm{CO}_{2}$-eq [2]. Data used for calculating the net effect of mineral nitrogen fertilizer are listed in Table 2.

\section{Results}

\subsection{Carbon footprint of agricultural production on the case farms}

\subsubsection{Arable farm: crop production}

4.1.1.1 Emissions in conventional LCA The GHG emissions from the arable farm, calculated using conventional LCA, are shown in Fig. 2. The main inputs were energy (electricity and diesel), seed, and mineral fertilizer. Almost half of the GHG emissions were associated with fertilization and
Table 2 Data used for calculating the net effect of mineral nitrogen fertilizer

\begin{tabular}{|c|c|c|c|}
\hline Description & Value & Unit & References \\
\hline Emissions of $\mathrm{CO}$-eq & 3.6 & $\mathrm{~kg} \mathrm{~kg}^{-1} \mathrm{~N}$ & [34] \\
\hline $\begin{array}{l}\text { Energy use for production of } \\
11 \mathrm{~kg} \mathrm{~N}\end{array}$ & 37 & MJ & [38] \\
\hline Carbon content in wheat (DM) & 45 & $\%$ & [17] \\
\hline Energy in wheat (85\% DM) & 14.4 & MJ & [39] \\
\hline Fuel for farming and harvest & 88 & $\mathrm{~L} \mathrm{ha}^{-1}$ & [40] \\
\hline Diesel, energy content & 35.3 & $M J L^{-1}$ & [38] \\
\hline Diesel, primary energy factor & 1.1 & & [41] \\
\hline \multicolumn{4}{|c|}{$\begin{array}{l}\text { Greenhouse gas (GHG) emissions, incl. conversion from primary } \\
\text { energy in: }\end{array}$} \\
\hline Production, diesel & 11 & $\mathrm{~g} \mathrm{CO}_{2}$-eq $\mathrm{MJ}^{-1}$ & {$[38]$} \\
\hline Tractor, diesel & 81.2 & $\mathrm{~g} \mathrm{CO}_{2}$-eq $\mathrm{MJ}^{-1}$ & [38] \\
\hline Fuel oil for drying grain & 0.15 & $\mathrm{LL}^{-1}$ water & {$[42]$} \\
\hline
\end{tabular}

soil tillage (Fig. 2). However, these calculations ignored the carbon and energy in the products produced on the farm [16]. In total, the arable farm emitted $154 \mathrm{Mg} \mathrm{CO}_{2}$-eq (around $1.6 \mathrm{Mg} \mathrm{CO}_{2}$-eq per hectare). The emissions of GHG per kg product produced were as follows: cereals $0.35 \mathrm{~kg}$ $\mathrm{CO}_{2}$-eq, rapeseed $0.8 \mathrm{~kg} \mathrm{CO}_{2}$-eq, and hay $0.43 \mathrm{~kg} \mathrm{CO}_{2}$-eq per kg dry matter (DM).

4.1.1.2 Emissions in CC-LCA The CC-LCA model accounted for carbon bound in products produced on the arable farm. Total emissions were again $154 \mathrm{Mg} \mathrm{CO}_{2}$-eq, but 577 $\mathrm{Mg} \mathrm{CO}_{2}$-eq were bound as carbon in the crop products produced, while the carbon content in soil decreased by $0.076 \mathrm{Mg} \mathrm{C}$ per hectare and year, corresponding to 0.28 $\mathrm{Mg} \mathrm{CO}_{2}$-eq. In total, this resulted in net carbon binding of $395 \mathrm{Mg} \mathrm{CO}_{2}$-eq (3.9 Mg CO -eq. per ha). Thus, in this approach emissions were negative (net sink) for the four

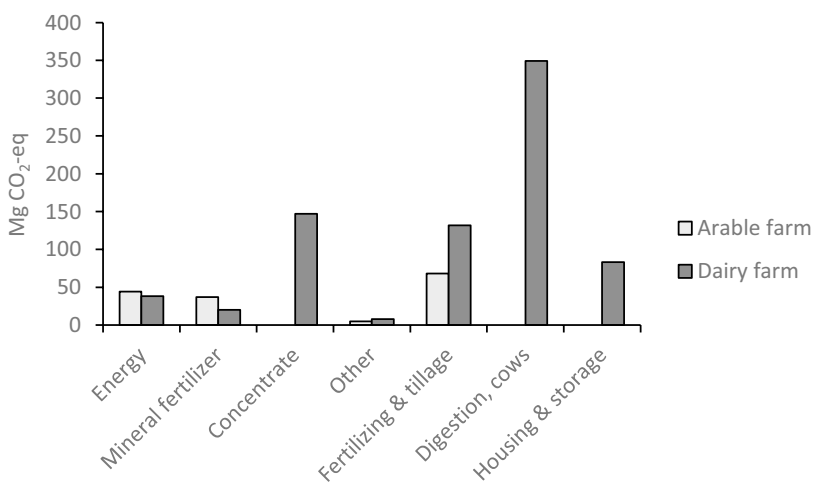

Fig. 2 Greenhouse gas (GHG) emissions from the arable farm and the dairy farm, including emissions associated with cultivating agricultural crops (fertilizer and tillage), dairy cow digestion, and manure management, calculated using conventional life cycle assessment (LCA) 


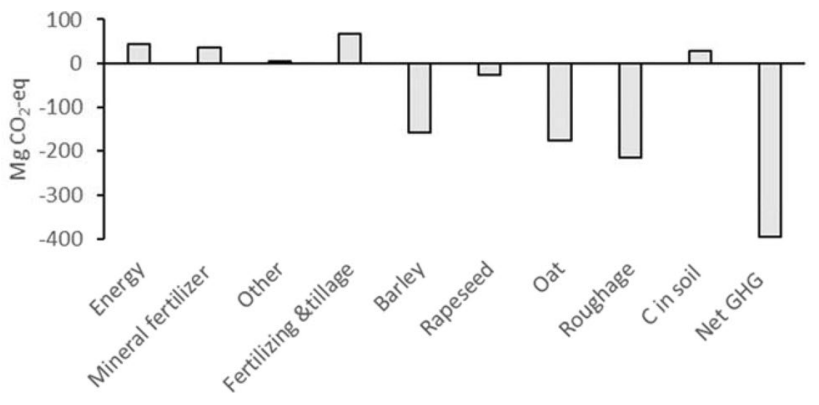

Fig. 3 Greenhouse gas (GHG) emissions from the arable farm, calculated using carbon capture-life cycle assessment (CC-LCA)

crops produced in the rotation on the arable farm and net GHG emissions were also negative (Fig. 3).

\subsubsection{Dairy farm: milk and meat production}

4.1.2.1 Emissions in conventional LCA The GHG emissions from the dairy farm, calculated using conventional LCA, are shown in Fig. 2. The main inputs were energy (electricity and diesel), mineral fertilizer, feed concentrate, bedding material, etc. Feed digestion is normally the largest contributor of GHG emissions in environmental assessments of dairy farms, since the methane produced in the rumen of ruminants is a powerful GHG, in these calculations 25 -fold stronger than $\mathrm{CO}_{2}$ [2]. For the dairy farm, primarily producing milk and beef, conventional LCA revealed large emissions of GHG $\left(777 \mathrm{Mg} \mathrm{CO}_{2}\right.$-eq), around $10 \mathrm{Mg} \mathrm{CO}_{2}$-eq per dairy cow. Almost $50 \%$ of these emissions derived from rumen digestion (Fig. 2). Some of the carbon in inputs such as feed concentrate is released as $\mathrm{CH}_{4}$ during digestion, and during storage and use of manure (Fig. 2). Emissions from the use of electricity were marginal, since it originated from hydropower. A part of these emissions is related to the animals sold. In this case, we allocated $85 \%$ of the emissions to the milk and $15 \%$ to sold animals [43]. The GHG emissions per kg energycorrected milk (ECM) were $0.86 \mathrm{~kg} \mathrm{CO}_{2}$-eq, which is low in an international perspective [44]. In the conventional LCA, only the emissions resulting from production, i.e., the "costs," were considered.

4.1.2.2 Emissions in CC-LCA The CC-LCA approach resulted in similar emissions of GHG from the dairy farm as conventional LCA (739 $\mathrm{Mg} \mathrm{CO}_{2}$-eq) (Fig. 4). The carbon in purchased concentrate, straw, etc. was included in the calculations. The dairy farm bought $263 \mathrm{Mg}$ dry matter (DM) of feed concentrate. With a carbon content of $45 \%$, the purchased feed concentrate contained $118 \mathrm{Mg}$ carbon. This carbon was sequestered by another farm and $434 \mathrm{Mg} \mathrm{CO}$-eq $(118 \times 3.68)$ was accredited to the pro-

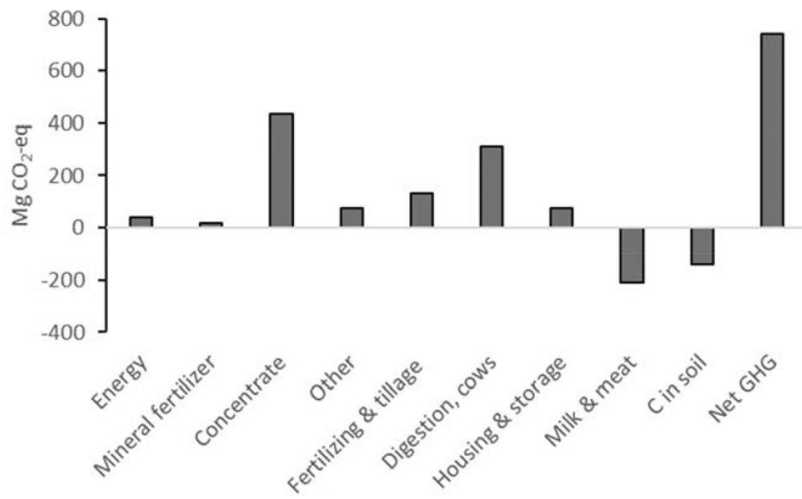

Fig. 4 Greenhouse gas (GHG) emissions from the dairy farm, calculated using carbon capture-life cycle assessment (CC-LCA)

ducer of the feed concentrate. In the CC-LCA, this purchased carbon was a load for the purchasing dairy farm (Fig. 4). A part of the purchased carbon (counted in $\mathrm{CO}_{2}$ ) is emitted by digestion as methane. In this case, $13.9 \mathrm{Mg}$ methane was emitted by the cows' digestion, corresponding to $349 \mathrm{Mg} \mathrm{CO}_{2}$-eq (Fig. 2). To avoid double-counting of the purchased carbon, the emissions from digestion were reduced; $13.9 \mathrm{Mg}$ methane contains $10.4 \mathrm{Mg}$ carbon and, counted in $\mathrm{CO}_{2}$, the $\mathrm{GHG}$ effect was $38 \mathrm{Mg} \mathrm{CO}_{2}$-eq.

In the same way, the emissions from "Housing and storage" (Fig. 2) were adjusted. These emissions were $83 \mathrm{Mg}$ $\mathrm{CO}_{2}$-eq and consisted of $0.1 \mathrm{Mg}$ nitrous oxide $\left(\mathrm{N}_{2} \mathrm{O}\right)$ and 2.1 $\mathrm{Mg}$ methane. Nitrous oxide is a very strong $\mathrm{GHG}, 298$-fold stronger than $\mathrm{CO}_{2}$, but contains no carbon. However, the emitted methane contained $1.6 \mathrm{Mg}$ carbon, corresponding to $6 \mathrm{Mg} \mathrm{CO}_{2}$-eq. The emissions for "Housing and storage" were therefore reduced by $6 \mathrm{Mg} \mathrm{CO}_{2}$-eq. (Figure 4).

The carbon content in soil on the dairy farm increased by $0.38 \mathrm{Mg} \mathrm{C}$ per hectare and year $\left(1.4 \mathrm{Mg} \mathrm{CO}_{2}\right.$-eq) [45], as shown by the negative value for " $\mathrm{C}$ in soil" in Fig. 4. The emissions from milk and meat were also negative, but net emissions were still high.

\subsection{Net effect of mineral fertilizer use according to CC-LCA}

Input and output GHG emissions for a winter wheat crop in Sweden receiving different mineral fertilizer doses in field trials are shown in Table 3.

Based on field trial data, the official recommendation for southern Sweden is to fertilize winter wheat with 200 $\mathrm{kg} \mathrm{N}$ per hectare when the expected yield is $9 \mathrm{Mg}$ wheat per hectare [37]. In the CC-LCA calculations on the field trial data, increasing the fertilizer rate from 0 to $200 \mathrm{~kg}$ $\mathrm{N}$ per hectare increased carbon sequestration in the harvested product by more than $2 \mathrm{Mg}$ (Table 3), which means that about $7.6 \mathrm{Mg} \mathrm{CO}_{2}$ was taken from the air. When the 
Table 3 Emissions of greenhouse gases (GHG), carbon content in grain, and estimated net binding of $\mathrm{CO}_{2}$ for different fertilizer doses tested in field trials with winter wheat in southern Sweden

\begin{tabular}{|c|c|c|c|c|c|c|c|}
\hline Field fertilization, $\mathrm{kg} \mathrm{N} \mathrm{ha}^{-1}$ & 0 & 80 & 120 & 160 & 200 & 240 & 280 \\
\hline Emissions from production of fertilizer, $\mathrm{CO}_{2}$-eq & 0 & 288 & 432 & 576 & 720 & 864 & 1008 \\
\hline Emissions in field when fertilizing, $\mathrm{CO}_{2}$-eq (see eq. 1 ) & 0 & 375 & 562 & 749 & 937 & 1124 & 1311 \\
\hline Yield, $\mathrm{kg} \mathrm{ha}^{-1}$ grain dry matter (excl. seed) & 2924 & 5854 & 6774 & 7357 & 7556 & 7670 & 7804 \\
\hline Yield, $\mathrm{kg} \mathrm{ha}^{-1}$ carbon in grain & 1316 & 2634 & 3048 & 3311 & 3400 & 3451 & 3512 \\
\hline Yield, $\mathrm{kg} \mathrm{ha}^{-1}$ carbon bound $\mathrm{CO}_{2}$-eq & 4839 & 9689 & 11,211 & 12,176 & 12,506 & 12,694 & 12,916 \\
\hline Management, harvest \& drying of grain, $\mathrm{CO}_{2}$-eq & 371 & 452 & 478 & 494 & 499 & 503 & 506 \\
\hline Net binding, $\mathrm{CO}_{2}$-eq & 4468 & 8574 & 9740 & 10,357 & 10,350 & 10,203 & 10,090 \\
\hline Net binding, $\mathrm{CO}_{2}$-eq with basic yield ${ }^{\mathrm{a}}$ excluded & 0 & 4106 & 5272 & 5889 & 5882 & 5735 & 5622 \\
\hline $\begin{array}{l}\text { Factor relating } \mathrm{CO}_{2} \text {-eq bound to that emitted in fertilizer } \\
\text { production (excl. zero fertilization) }\end{array}$ & 0 & 14 & 12 & 10 & 8 & 7 & 6 \\
\hline
\end{tabular}

${ }^{a}$ Wheat harvested without any mineral nitrogen fertilizer (basic yield). Final yield minus basic yield shows the effect of the fertilizer

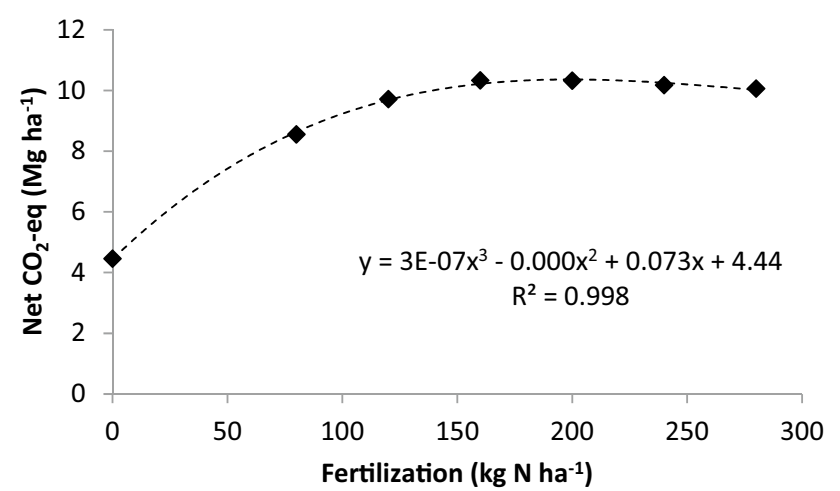

Fig. 5 Net amount of carbon dioxide $\left(\mathrm{CO}_{2}\right.$-eq, $\mathrm{Mg}$ per ha) sequestered by winter wheat grain at different fertilization levels $(\mathrm{kg} \mathrm{N}$ $\mathrm{ha}^{-1}$ ). Greenhouse gas (GHG) emissions from fertilizer production, cultivation, and drying of grain deducted. Straw is an additional bonus, i.e., it is not included in these calculations. Data taken from field trials (10-year average) in southern Sweden used by Swedish Board of Agriculture [36]

GHG emissions from the production of fertilizer, cultivation, and grain drying were subtracted, there was still a positive outcome in terms of reduced GHG emissions. When no nitrogen fertilizer was used, there was a level of yield called "basic yield" in Table 3. When this basic yield was subtracted from the yield obtained for the fertilized wheat crop, there was still a positive outcome in terms of reduced GHG emissions (Table 3, Fig. 5).
At a nitrogen dose of $200 \mathrm{~kg}$ per ha, each $1 \mathrm{~kg}$ of nitrogen was estimated to bind (net) $29 \mathrm{~kg} \mathrm{CO}_{2}$-eq, while at lower fertilization rates the amount bound was higher (37-51 kg CO ${ }_{2}$-eq) (Table 4). Energy binding in grain and net energy consumption also showed a positive trend when photosynthesis was boosted by the application of nitrogen fertilizer, up to a certain level (Table 5 and Fig. 6).

\section{Discussion}

\subsection{Carbon footprint of agricultural production}

Agriculture is important as the main producer of food for the global population. Despite this, agriculture is often regarded as an environmental problem and, at least in Sweden, is being instructed to redirect by politicians, although seldom based on sound scientific evidence. Products from agriculture can be used as food, fibers, substrate for bioenergy production, as a carbon sink in soil, for textiles, or in the technosphere. In the transport and energy sectors, energy conversion efficiency is always calculated. Moreover, it is known that some fossil fuels, such as diesel, are needed for the production of biofuels. For example, production of wood chips for combined heat and power generation needs an energy input of $4-5 \%$ of the energy content in the wood chips [46]. This energy can originate from renewable sources. It is also well known that the vehicle industry reports fuel input per $\mathrm{km}$ traveled

Table 4 Estimated amount of carbon dioxide bound in winter wheat grain, i.e., carbon sequestration, at different levels of mineral nitrogen fertilizer (yield with zero fertilizer (basic yield) deducted)

\begin{tabular}{llrrrrrr}
\hline Fertilizer rate in field, $\mathrm{kg} \mathrm{N} \mathrm{ha}^{-1}$ & 0 & 80 & 120 & 160 & 200 & 240 \\
Net binding in grain, $\mathrm{kg} \mathrm{CO}_{2}$-eq per kg N applied & 0 & 51 & 44 & 37 & 29 & 24 \\
\hline
\end{tabular}


Table 5 Estimated energy outputs in harvested winter wheat, energy inputs for cultivation and drying of grain, and net yield of energy

\begin{tabular}{|c|c|c|c|c|c|c|c|}
\hline Fertilizer rate, $\mathrm{kg} \mathrm{N}$ & 0 & 80 & 120 & 160 & 200 & 240 & 280 \\
\hline Energy for production of fertilizer & 0 & 2960 & 4440 & 5920 & 7400 & 8880 & 10,360 \\
\hline Yield, kg per ha $15 \%$ moisture (seed excluded) & 3440 & 6887 & 7969 & 8655 & 8890 & 9023 & 9181 \\
\hline Energy in harvested grain, MJ, 15\% moisture (seed excluded) & 49,536 & 99,173 & 114,754 & 124,632 & 128,016 & 129,931 & 132,206 \\
\hline Management and drying of grain, MJ & 45,103 & 90,811 & 104,608 & 112,814 & 114,652 & 115,050 & 115,801 \\
\hline Net energy, MJ, after management and drying & 48,565 & 89,078 & 103,352 & 111,116 & 115,025 & 115,246 & 118,763 \\
\hline Net energy, MJ excluding basic harvest ${ }^{a}$ & 0 & 45,708 & 59,505 & 67,711 & 69,549 & 69,947 & 70,698 \\
\hline Energy gain, $\mathrm{MJ}$, per kg N, counted stepwise & 0 & 571 & 496 & 423 & 348 & 291 & 252 \\
\hline Energy gain divided by energy used for fertilizer production & 0 & 15 & 13 & 11 & 9 & 8 & 7 \\
\hline
\end{tabular}

aYield at zero $\mathrm{N}$ fertilization

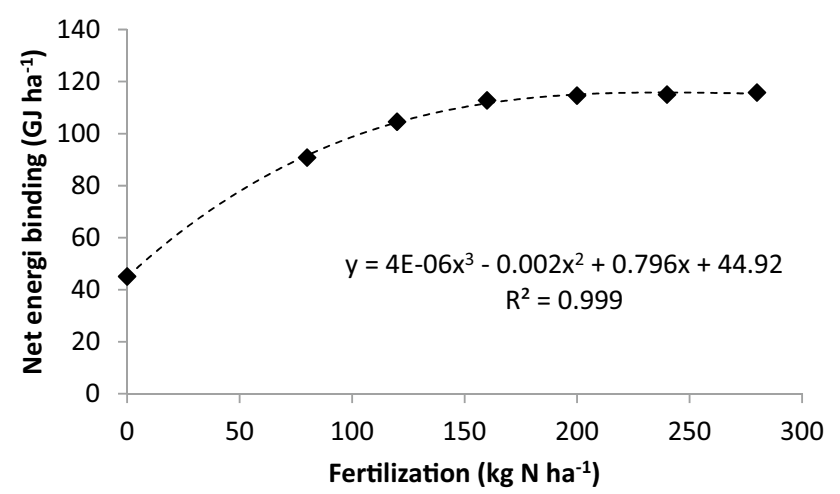

Fig. 6 Net energy binding (i.e., net energy gain, GJ ha ${ }^{-1}$ ) in winter wheat grown at different fertilization levels $\left(\mathrm{kg} \mathrm{N} \mathrm{ha}^{-1}\right)$. Energy consumption in fertilizer production, cultivation, and drying of grain deducted. Straw is an additional bonus, i.e., it is not included in these calculations

[47]. This is an approach that the agricultural sector needs to adopt so that labeling certification systems for agriculture take the efficiency of agriculture into account. To achieve this, it is necessary to find a way to value the energy content and quality of protein produced on the finite area of arable land available worldwide.

Our CC-LCA estimates for the case of a Swedish arable farm showed that when carbon capture in products was included, crop production became a net sink of GHG. In our case, the net emissions of GHG were negative, and the net carbon sequestration was almost $4 \mathrm{Mg}$ per hectare. The sequestered carbon is sold to consumers, humans, animal farms, or energy users. This ecosystem service of sequestering carbon and delivering it in a product suitable for human food should be valued in the accounting system for climate impact.

The climate impact of ruminants has been widely debated since the FAO published its critical report in 2006 [48], and it is generally claimed that ruminant livestock contributes to climate change due to emissions of methane during digestion [49]. Our calculations for a case dairy farm in Sweden confirmed that the carbon content in milk and beef products did not compensate for the methane emissions from ruminant digestion (Fig. 4). However, the CC-LCA method of calculation equates the energy in milk and meat to that in wood chips (carbon as carbon), which is an unfair comparison. From a nutritional perspective, carbon in milk and meat is more valuable than that in wood chips, which are inedible to both humans and animals. Ruminants mainly convert grass into milk and meat, which are important in many diets. Grass is not edible to humans. As shown by Sonesson et al. [50], it is possible to value the quality of proteins produced, instead of the amount of product, in LCA calculations. If the nutrient content in milk and meat were valued in comparison with wood chips, the outcome would probably be more positive for milk and meat production.

The environmental impact of consumption of meat, especially beef, is also widely criticized, but there are many areas where grazing animals supply ecosystem services such as biodiversity in the landscape [51]. Only $6 \%$ of GHG emissions from ruminants can be avoided if Sweden maintains its current grazed area [52]. Moreover, in some parts of the world, like northern Sweden, where only a few crops can cope with the short growing season and cold winters, ley and spring cereals for animal feed are the most profitable options for farmers. The most probable alternative land use would be forest, which is the dominant land use in Sweden, but that would reduce the biodiversity in these landscapes.

Analyses of the impact of agriculture on climate change should include both arable land and animal husbandry. Not all crops produced are of suitable quality for human food. If the baking properties of the wheat grain are low, it is classified as animal feed. By-products and rejected products from beer production, sugar production, bakeries, etc. are also used as animal feed. Moreover, ley is normally an important break crop in arable production, especially when growing crops like potatoes, oilseeds, beans, and peas. In other words, animal husbandry has several 
positive feedbacks to crop production. On a global scale, animal husbandry is a main driver for deforestation, due to the increasing demand for feed and grazing land. This indirect effect of agriculture on global land use change and associated GHG emissions was not included in our analysis, which focused on the farm scale. However, accounting for net carbon sequestration in products, instead of only focusing on emissions from inputs, would acknowledge the fact that good arable land is a limited resource.

\subsection{Net effect of mineral fertilizer use}

Our analysis showed that a balanced use of mineral nitrogen fertilizer can be effective in increasing carbon sequestration. A Swedish winter wheat crop grown using the recommended dose ( $200 \mathrm{~kg} / \mathrm{ha}$ ) of nitrogen fertilizer was estimated to bind about eight-fold more GHG in grain than was released during the production of the mineral fertilizer and cultivation of the crop (effects of zero fertilization and the additional benefits of wheat straw and soil carbon content are not included). While energy is needed in the production of mineral fertilizer, using fertilizer at the recommended rate in agriculture was estimated to return about nine-fold more energy in products (Table 5). Yara, the main producer of mineral fertilizers in Scandinavia, currently uses natural gas in manufacturing. The process could be improved from a climate perspective if energy from renewable sources was used. In pilot plants currently under construction, hydropower and solar energy will be used as energy inputs (Mogens Erlingson, Yara, personal communication, 2019).

As stated above, good arable land is a limited resource and needs to be used in a productive way. Balanced use of mineral fertilizer with a low carbon footprint, produced with best available technique, is an effective and environmentally sound way to increase the utilization of arable land.

\subsection{Effect of official accounting approach}

The Swedish EPA [2] reported an increase of almost 5\% in GHG emissions from agriculture between 2016 and 2017, partly due to increased use of mineral fertilizers and increased production of animals. Another report, on energy efficiency in Swedish agriculture, states that mineral fertilizers are energy-intensive and that, from an energy use perspective, it would be beneficial to decrease their use [53]. These conclusions are based solely on the emissions from the production of mineral fertilizer, while carbon sequestration in the products is ignored. Our CCLCA calculations for a Swedish winter wheat crop showed that increasing the fertilizer rate to the recommended level for the region substantially increased the carbon and energy content in the harvested product, while the net outcome was positive in terms of energy and reduced GHG emissions.

In 2010, the Swedish Parliament decided that environmental problems in Sweden would have to be resolved without increasing environmental and health problems outside Sweden's borders, an objective called the "generational goal." It can be pointed out that it is rare to include actual consumption when analyzing the environmental impact from agriculture. However, according to SEPA, $73 \%$ of the GWP caused by food consumption in Sweden in 2016 occurred in other countries, an 8\% increase from $2010[4,54]$. This figure will probably continue to increase in future if domestic food production is not valued for all its benefits, including its relatively low climate footprint. Food and feed imports can cause indirect land use change, where forests in other countries are converted to farmland, with consequences for climate change.

The global accounting system for climate impact (conventional LCA) only takes into account the costs (emissions), and not income (carbon and energy binding). Consequently, the positive effect of agricultural activities is overlooked, and agriculture appears to be a major contributor to greenhouse gas emissions. Future studies should seek to apply the CC-LCA approach to crop production systems in different countries and regions worldwide, which could help develop a fairer system for emissions accounting.

\section{Conclusions}

The main task for agriculture is to produce food by harnessing the power of photosynthesis, but carbon sequestration is not considered in official climate change calculations. A fairer approach to assess environmental impact would be to measure the net flow of GHG in agriculture, and not only the emissions, on farm and national level. When CC-LCA was applied to a case arable farm in Sweden, and carbon capture in products was included, crop production became a net sink of GHG, compared with a net source in LCA. For a dairy farm, both approaches gave similar results, mainly because energy in milk and meat is unfairly equated to that in wood chips. A separate CC-LCA analysis of winter wheat production in Sweden showed that balanced use of mineral nitrogen fertilizer can be effective in increasing carbon sequestration and net energy production. Thus, instead of conventional LCA, we recommend a carbon capture LCA (CC-LCA) approach that considers the sequestered carbon and allows the marginal utility of individual actions to be calculated.

Analyses of the impact of agriculture on climate change should be holistic and should include both arable land and 
animal husbandry. In some areas, it is not possible to grow cash crops for humans, but grazing animals can be used to produce food. Animals can also convert by-products and crops not fit for human consumption into high-quality food. Biodiversity is an important factor in ecological systems and, in areas where forest is the only option to agriculture, grazing animals increase biodiversity. In areas where crop production dominates, ley production and grazing by animals both increase biodiversity. Arable land is limited and needs to be used in an environmentally friendly and productive way. Crop production should be based on balanced use of mineral fertilizer, produced with best available technique, which increases the net binding of energy and carbon in harvest.

In order to enable environmentally sound decisionmaking and actions, the human-specific energy quality requirements in food should be valued in a similar way as specific fuel quality for cars. This would represent a significant change in the formulation of future political steering instruments and would require more climate-orientated labeling systems. Future approaches to steer consumers and policymakers toward more climate-friendly products and practices must acknowledge that agriculture sequesters carbon in raw products (food, fiber, renewable fuels).

Acknowledgements We wish to express our gratitude to the Home in Sweden Foundation at The Royal Swedish Academy of Agriculture and Forestry (Grant No. H14-0071-HIS) for financial support.

\section{Compliance with ethical standards}

Conflict of interest The authors declare they have no conflict of interest.

Open Access This article is licensed under a Creative Commons Attribution 4.0 International License, which permits use, sharing, adaptation, distribution and reproduction in any medium or format, as long as you give appropriate credit to the original author(s) and the source, provide a link to the Creative Commons licence, and indicate if changes were made. The images or other third party material in this article are included in the article's Creative Commons licence, unless indicated otherwise in a credit line to the material. If material is not included in the article's Creative Commons licence and your intended use is not permitted by statutory regulation or exceeds the permitted use, you will need to obtain permission directly from the copyright holder. To view a copy of this licence, visit http://creativecommons .org/licenses/by/4.0/.

\section{References}

1. UNFCCC (United Nations Framework Convention Climate Change) (2019) http://unfccc.int/essential_background/conve ntion/status_of_ratification/items/2631.php. Accessed May 2020

2. Swedish EPA (2019a) National Inventory Report Sweden 2019. Greenhouse Gas Emission Inventories 1990-2017 Submitted under the United Nations Framework Convention on Climate Change and the Kyoto Protocol

3. Sweden Statistics (2019) Statistikdatabasen [Data base] in Swedish. http://www.statistikdatabasen.scb.se. Accessed May 2020

4. Swedish EPA (2019b) Konsumtionsbaserade vaxthusgasutslapp per person och ar [Consumption-based greenhouse gas emissions per person per year] in Swedish http://www.utslappsha ndel.se/sv/Sa-mar-miljon/Statistik-A-O/Vaxthusgaser-konsu mtionsbaserade-utslapp-per-person. Accessed May 2020

5. ISO (2006a) Miljoledning: Livscykelanalys: Principer och struktur [Environmental management -Life cycle assessment- Principles and framework] in Swedish. SS-EN ISO 14040:2006. SIS Forlag, Stockholm

6. ISO (2006b) Miljoledning: Livscykelanalys: Krav och vagledning [Environmental management -Life cycle assessment- Requirements and guidelines] in Swedish. SS-EN ISO 14044:2006. SIS Forlag, Stockholm

7. Baumann H, Tillman AM (2004) The hitch hiker's guide to LCA. An orientation in life cycle assessment methodology and application. Lund: Studentlitteratur

8. Focus on Nutrients (2019) http://www.greppa.nu/om-grepp a/om-projektet/in-english.html. Accessed May 2020

9. DeCicco JM (2012) Biofuels and carbon management. Clim Change 111:627-640

10. Frankelius $P$ (2020) A proposal to rethink agriculture in the climate calculations, Agronomy Journal (published by American Society of Agronomy). In press. https://doi.org/10.1002/ agj2.20286

11. SSNC (Swedish Society for Nature Conservation). https://www. naturskyddsforeningen.se/ekologisk-odling-klimatpaverkan. Accessed May 2020 (in Swedish)

12. UNFCCC (United Nations Framework Convention Climate Change) (1992) http://unfccc.int/resource/docs/convkp/conve ng.pdf. Accessed May 2020

13. United States Department of Agriculture (2019) https://www. ams.usda.gov/rules-regulations/organic/labeling. Accessed May 2020

14. Searchinger TD, Wirsenius S, Beringer T et al (2018) Assessing the efficiency of changes in land use for mitigating climate change. Nature 564:249-253. https://doi.org/10.1038/s4158 6-018-0757-z

15. Swedish Board of Agriculture (2019a) VERA [a calculation tool] https://adm.greppa.nu/vera.html. Accessed May 2020 (in Swedish)

16. Berglund M (2015) Manual som beskriver Klimatkollen: klimatberakningar i VERA [Manual describing the climate calculations in VERA] in Swedish. http://adm.greppa.nu/downl oad/18.77f61041167329de2ec48caf/1542812559623/klima tberakningar-vera-2015.pdf. Accessed May 2020

17. ECN, Phyllis 2. Database https://www.ecn.nl/phyllis2. Accessed May 2020

18. Lindmark Mansson H (2012) Den svenska mjolkens sammansattning 2009, Rapport nr: 7094. In Swedish. En forskningsrapport från Svensk Mjolk. [The composition of Swedish milk]

19. Jonsson H, Baky A, Jeppson U, Hellstrom D, Karrman E (2005) Composition of urine, faeces, greywater and biowaste: for utilisation in the URWARE model, Urban Water report 2005:6. Chalmers University of Technology, Urban Water

20. Hogberg A, Pickova J (2002) Du blir vad du ater: fettsyror i foder, kott och manniska. Fakta Jordbruk Nr 11 2002. [You become what you eat: fatty acids in feed, meat and humans.] in Swedish. http://fabod.nu/wp-content/uploads/du_blir_ vad_du_ater.pdf. Accessed May 2020

21. Rosén A (2013) Aktuella trender inom notkottsproduktionen, Institutionen för livsmedelskunskap nr 384, SLU 
22. Katterer T, Andrén O (2001) The ICBM family of analytically solved models of soil carbon, nitrogen and microbial biomass dynamics: descriptions and application examples. Ecol Model 136:191-207

23. Lokupitiya E, Paustian K, Easter M, Williams S, Andrén O, Katterer T (2012) Carbon balances in US croplands during the last two decades of the twentieth century. Biogeochem 107:207-225

24. Borgen SK, Grønlund A, Andrén O, Katterer T, Tveito OE, Bakken LR, Paustian K (2012) CO2 emissions from cropland in Norway estimated by IPCC default and Tier 2 methods. Greenhouse Gas Meas Manage 2:5-21

25. Andrén O, Katterer T, Karlsson T (2004) ICBM regional model for estimations of dynamics of agricultural soil carbon pools. Nutr Cycl Agroecosyst 70:231-239

26. Andrén O, Katterer T, Karlsson T, Eriksson J (2008) Soil C balances in Swedish agricultural soils 1990-2004, with preliminary projections. Nutr Cycl Agroecosyst 81:129-144

27. Prade T, Katterer T, Bjornsson L (2017) Including a one-year grass ley increases soil organic carbon and decreases greenhouse gas emissions from cereal-dominated rotations: a Swedish farm case study. Biosys Eng 164:200-212

28. Tidaker P, Sundberg C, Oborn I, Katterer T, Bergkvist G (2014) Rotational grass/clover for biogas integrated with grain production: A life cycle perspective. Agric Syst 129:133-141

29. Tidaker $\mathrm{P}$, Bergkvist $\mathrm{G}$, Bolinder $\mathrm{M}$, Eckersten $\mathrm{H}$, Johnsson $\mathrm{H}$, Katterer T, Weih M (2016) Estimating the environmental footprint of barley with improved nitrogen uptake efficiency: a Swedish scenario study. Eur J Agron 80:45-54

30. Tidaker P, Wesstrom $T$, Katterer $T$ (2017) Energy use and greenhouse gas emissions from turf management of two Swedish golf courses. Urban For Urban Green 21:80-87

31. Bonesmo H, Beauchemin KA, Harstad OM, Skjelvag AO (2013) Greenhouse gas emission intensities of grass silage based dairy and beef production: a systems analysis of Norwegian farms. Livestock Sci 152:239-252

32. Krobel $\mathrm{R}$, Bolinder MA, Janzen $\mathrm{HH}$, Little $\mathrm{SM}$, Vandenbygaart $\mathrm{AJ}$, Katterer T (2016) Canadian farm-level soil carbon change assessment through the combination of the greenhouse gas model Holos with the Introductory Carbon Balance Model (ICBM). Agric Syst 143:76-85

33. Bolinder MA, Janzen HH, Gregorich EG, Angers DA, Vandenbyggart AJ (2007) An approach for estimating net primary productivity and annual carbon inputs to soil for common agricultural crops in Canada. Agric Ecosyst Environ 118:29-42

34. Yara (2019) https://www.yara.com/crop-nutrition/why-fertilizer /environment/fertilizer-life-cycle. Accessed May 2020

35. Swedish Board of Agriculture (2018a) Farm animals in June 2018. JO 20 SM 1801. In Swedish with English summery

36. Swedish Board of Agriculture (2016) Rekommendationer for godsling och kalkning 2017. Jordbruksinformation 24, 2016. http:// www2.jordbruksverket.se/download/18.4da45f4e158df6b017b4 9d79/1481272555089/jo16_24v2.pdf. Accessed May 2020

37. Swedish Board of Agriculture (2018b) Rekommendationer for godsling och kalkning 2019 [Recommendations for fertilizing and liming in 2019] in Swedish. Jordbruksinformation 18: 2018. https ://www2.jordbruksverket.se/download/18.47f1061167704c0 9faaa019/1543994500651/jo18_18v2.pdf. Accessed May 2020

38. Berglund $M$, Cederberg $C$, Clason C, Henriksson M,Torner $L$ (2009) Jordbrukets klimatpaverkan: underlag for att berakna vaxthusgasutslapp pa gardsniva och nulagesanalyser av exempelgardar [Agriculture's climate impact: basis for calculating greenhouse gas emissions at farm level and current situation analyzes of example farms] in Swedish. HS Halland [Swedish Rural Economy and Agricultural Societies in Halland]

39. Hadders G, Mehrdad A, Nilsson C, Burvall J (2001) Bransleegenskaper hos spannmalskarna. Betydelsen av jordart, sadesslag och sort [Grain core fuel properties. Importance of soil, cereals and variety] in Swedish. Report 289, JTI

40. County Administration Board (2019) Bidragskalkyler [Variable costing calculations] in Swedish. Lansstyrelsen Vastra Gotaland. https://www.lansstyrelsen.se/download/18.5e83a30f169d902 92dfe5db/1555339884272/bidragskalkyler-konv-2019.pdf. Accessed May 2020

41. Ahlgren S, Baky A, Bernesson S, Nordberg A, Norén O, Hansson PA (2010). Det svenska jordbrukets framtida drivmedelsforsorjning [Future Vehicle Fuel Supply for Swedish Agriculture] In Swedish with English Summery. Report 20-2010. Department of Energy and Technology. Swedish University of Agricultural Sciences, Uppsala. https://pub.epsilon.slu.se/4684/1/ahlgr en_s_et_al_100518.pdf. Accessed May 2020

42. Edstrom M, Pettersson O, Nilsson L, Horndahl T (2005) Jordbrukssektorns energianvandning [Energy use in the agricultural sector] in Swedish. JTI- rapport 342

43. Brien DO, *Capper JL, Garnsworthy PC, Grainger C, Shalloo L (2014) A case study of the carbon footprint of milk from highperforming confinement and grass-based dairy farms. J Dairy Sci 97(3):1835-1851. https://doi.org/10.3168/jds.2013-7174

44. FAO (2010) Greenhouse gas emissions from the dairy sector a life cycle assessment

45. Andrén O, Katterer T (1997) ICBM: the introductory carbon balance model for exploration of soil carbon balances. Ecol Appl 7:1226-1236

46. Borjesson $P$ (1996) Energy analysis of biomass production and transportation. Biomass Bioenergy Volym 11(4):305-318

47. European Environment Agency. Indicator 20: Energy and $\mathrm{CO}_{2}$ intensity. https://www.eea.europa.eu/publications/ENVISSUENo 12/page027.html. Accessed May 2020

48. FAO (2006) Livestock's long shadow: environmental issues and options. Food and Agriculture Organization of the United Nations, Rome

49. Bryngelsson D, Wirsenius S, Hedenus F, Sonesson U (2016) How can the EU climate targets be met? A combined analysis of technological and demand-side changes in food and agriculture. Food Policy 59:152-164

50. Sonesson U, Davis J, Flysjo A, Gustavsson J, Witthoft C (2016) Protein quality as functional unit: a methodological framework for inclusion in life cycle assessment of food. J Clean Prod 140:1-9. https://doi.org/10.1016/j.jclepro.2016.06.115

51. Taube F, Gierus M, Hermann A, Loges R, Schonbach P (2014) Grassland and globalization-Challenges for north-west European grass and forage research. Grass Forage Sci 69:2-16

52. Swedish Board of Agriculture (2012) Ett klimatvanligt jordbruk 2050 [Climate friendly agriculture by 2050]. In Swedish, with English Summary. Report 2012:35. https://www2.jordbruksv erket.se/webdav/files/SJV/trycksaker/Pdf_rapporter/ra12_35b. pdf. Accessed May 2020

53. Swedish Board of Agriculture (2011) Energieffektivisering inom jordbruket. Forslag till utformning av radgivningssystem [Energy efficiency in agriculture. Draft the design of advisory system] in Swedish. Report 2011:1. http://www2.jordbruksv erket.se/webdav/files/SJV/trycksaker/Pdf_rapporter/ra11_12. pdf. Accessed May 2020

54. Swedish EPA (2012) Konsumtionsbaserade miljoindikatorer (Consumption based environmental indicators) in Swedish with English Summery. Report 6483. http://www.naturvards verket.se/Documents/publikationer6400/978-91-620-6483-9. pdf?pid=3791. Accessed May 2020

Publisher's Note Springer Nature remains neutral with regard to jurisdictional claims in published maps and institutional affiliations. 